\title{
Mechanisms underlying recovery of zooplankton in Lake Orta after liming
}

\author{
Roberta PISCIA, ${ }^{1 *}$ Norman D. YAN, ${ }^{2}$ Marina M. MANCA ${ }^{1}$ \\ ${ }^{1}$ National Research Council, Institute of Ecosystem Study Largo Tonolli 50, 28922, Verbania, Italy; ${ }^{2}$ Biology Department, \\ York University, Toronto, Ontario, and Dorset Environmental Science Centre, Box 39, Dorset, Ontario, Canada, P0A 1E0 \\ *Corresponding author: r.piscia@ise.cnr.it
}

\begin{abstract}
The goal of this study was to improve the understanding of the large-scale mechanisms underlying the recovery of the zooplankton of Lake Orta from historical contamination, following reduced input of ammonia and metals and the subsequent 1989/90 liming intervention. The industrial pollution had been severe and long-lasting (1929-1990). Zooplankton biodiversity has improved, but most of the new taxa appearing in our counts are rotifers, while many calanoids and the large cladoceran predators (Bythotrephes and Leptodora) that are common in the nearby Lake Maggiore, were still absent from Lake Orta 17 years after liming. To aid understanding of the large-scale mechanisms controlling changes in annual richness, we assessed the annual persistence (P) of Crustacea and Rotifera taxa as an estimator of whether propagules that survived introduction, as result of the natural recolonization process, also thrived. We found that the rate of introduction of zooplankton colonists and their persistence in the water column of Lake Orta changed from 1971 to 2007. New rotifer taxa appeared in the lake after the mid-1980s, when discharge of toxic substances decreased, but their annual persistence was low $(P<0.5)$ until the turn of the century. The numerical values of rotifer and crustacean persistence in Lake Orta were unexpectedly high in 2001 and 2007 (0.55 and 0.72 for rotifers, 0.85 and 0.86 for crustacean, respectively), much higher than in limed lakes in Sudbury, Canada, and in adjacent Lake Maggiore. We hypothesize this could be related to the lack of Cladoceran predators and zooplanktivorous fish in the pelagic waters of Lake Orta.
\end{abstract}

Key words: Annual persistence; annual taxa richness; pollution; zooplankton; Lake Orta.

Received: October 2015. Accepted: December 2015.

\section{INTRODUCTION}

Lakes have been acidified by acid mine drainage, liquid industrial effluents, and by the long-range transport of air pollutants. While long-range transport of sulfur and nitrogen oxides was the dominant cause of lake acidification in eastern North America and Scandinavia (Henriksen et al., 1988; Renberg et al., 1990; Dillon et al., 1987), Lake Orta, in northern Italy was acidified by decades of in situ oxidation of liquid ammonia waste from a textile plant. In addition, it was contaminated by heavy metals including copper, chromium, zinc, cadmium, and aluminum associated with metal plating industries in its watershed (Calderoni et al., 1990; Calderoni and Tartari, 2001; Bonacina, 2001). Pollution of Lake Orta started in 1926 and within a few years damage to biota was so severe that its waters were deemed sterile (Monti, 1930). It was not until 1980 that the chemical improvement in the lake finally began when new regulations required substantial reductions in the discharge of pollutants. Recovery was then accelerated by a massive in-lake liming intervention in 1989-1990 (Calderoni et al., 1990), which brought the water column $\mathrm{pH}$ back to circum-neutrality, inducing the precipitation of a large proportion of the dissolved metals from the water column into the sediments (Calderoni and Tartari, 2001). Zooplankton community structure responded promptly to these improvements in water quality, increasing in diversity (Bonacina, 2001).

Given many successful efforts to reduce both acid deposition and liquid industrial effluents to receiving waters, the attention of aquatic ecologists has turned to what factors regulate the pace, extent and dynamics of recovery of previously damaged communities (Monteith et al., 2005; Keller et al., 2007). For lakes that were historically damaged by atmospheric acid inputs, both external (colonist delivery to the pelagic community from the metacommunity or egg bank) and internal (colonist survival and growth) factors may be important, and which are more important can vary among lake regions and over time (Gray and Arnott, 2012). In lake-rich regions such as the Canadian Shield, there are many colonist sources, and, for these lakes, internal processes appear to dominate, i.e. not the rate of arrival of colonists but their subsequent ability to survive and thrive (Yan et al., 2016). We know less about the key drivers of recovery in historically acidified Lake Orta, which likely has fewer natural sources of colonists because it is not in a lake-rich region, at least in comparison with the Canadian Shield. It does, however, have a longer history of human development, and people do increase colonist delivery rates, sometimes by many fold (Hebert and Cristescu, 2002; Williamson, 1996). Because of these differences in the metacommu- 
nity and in its development history, we might expect that the key mechanisms underlying recovery in Lake Orta may differ from those underlying recovery of atmospherically-acidified lakes on the Canadian or Scandinavian shields. Differences may also arise because of differences in the water quality trajectories in Lake Orta when compared with atmospherically-acidified lakes.

Here our goal is to improve the understanding of the large-scale mechanisms underlying the recovery of the zooplankton of Lake Orta from historical contamination following the 1989/90 liming (Bonacina, 2001). Our specific objectives were to determine: i) if the rate of introduction of zooplankton colonists or their persistence in the water column of Lake Orta have changed over time; ii) if changes in colonist introduction rates are correlated with anthropogenic or natural changes in the watershed; and iii) which changes in the lake's water quality best correlate with observed changes in annual persistence of zooplankton colonists in the recovering pelagic community. While the pattern of recovery of the zooplankton community of Lake Orta soon after liming has been described (Manca and Comoli, 1995; Bonacina, 2001; Signorini, 2005), to date possible zoogeographic vs ecotoxicological mechanisms that underpin this recovery have not been examined. We hypothesized: i) that the rate of introduction of colonists would have increased over time as settlement and use of the watershed increased; and ii) that the annual persistence of these colonists increased because of improvements in water quality, especially increases in $\mathrm{pH}$ and decreases in $\mathrm{Cu}$ levels after liming and changes in industrial practices. While changes in fish predation also appears to influence annual persistence of recovering zooplankton assemblages in Canada (Yan et al., 2016), the continued absence of native, pelagic zooplanktivorous fish in Lake Orta (Volta et al., 2016), and in pelagic, micro-invertebrate predators (Bonacina, 2001; Signorini, 2005) suggested to us that predators were likely as important as water quality changes as regulators of annual persistence.

\section{METHODS}

Lake Orta, the seventh largest Italian lake by volume, is a deep $\left(\mathrm{z}_{\max }=143 \mathrm{~m}, \overline{\mathrm{z}}=71 \mathrm{~m}\right)$, warm, oligo-monomictic lake located in the Italian subalpine region. Details about pollution history and chemistry are described in Rogora et al. (2016).

Zooplankton samples were collected in the vicinity of a station corresponding to the maximum depth of the lake with a Clarke-Bumpus plankton sampler equipped with a $76 \mu \mathrm{m}$ nylon net, which from previous experiment resulted to be representative of zooplankton population, both crustacean and rotifers (Monogononta; Ramoni, 1997). We sampled from a boat cruising at a low, constant speed $\left(0.6 \mathrm{~m} \mathrm{~s}^{-1}\right)$, raising and lowering the net two times through $50 \mathrm{~m}$ in a sinusoidal trajectory and filtering at least $1000 \mathrm{~L}$ of lake water (de Bernardi, 1984). The resulting integrated samples are little influenced by the occurrence of plankton swarms and represent the pelagic community, which is mainly restricted to the upper $50 \mathrm{~m}$ of the water column (Manca et al., 2000). In all years, samples were immediately fixed in $90 \%$ denatured ethanol and then transferred into $10 \%$ formaldehyde. Using identical methods at all times, zooplankton were sampled monthly in 1971, 1980, 1981, 1986, 1988-1998 inclusive, 2001 and 2007. Zooplankton were identified to species wherever possible and counted at $63 \mathrm{x}$ magnification. At least $10 \%$ of the total sample volume was examined (Manca et al., 1992).

Here we used the approach suggested by Yan et al. (2016) to calculate rates that colonists arrived, survived and thrived each year from the encountering of species new to our records in the lake, and from annual species persistence metrics. While Yan et al. (2016) compared lakes, here we mainly compared different blocks of times and differing groups of zooplankton (i.e., rotifers $v s$ groups of Crustacea). We examined the temporal dynamics of the accumulation of novel species $(\mathrm{N})$, and the annual persistence of taxa $(\mathrm{P})$, and their correlations with logical driver variables (i.e. chemical variables as determinants of $\mathrm{P}$, and rotifer resting eggs abundances in sediment, human population and wind data from Maggiore as determinants of N, respectively reflecting in situ colonization potential, human assisted and natural dispersal vectors). We had no wind data from Lake Orta, but for reasons given in Sturman and Wanner (2001), we are confident that wind data from nearby Lake Maggiore can serve as an effective proxy for wind fields over Lake Orta.

Annual persistence of species (P) was calculated according to the following equation:

$$
\mathrm{P}=1-((\mathrm{ST}-\mathrm{S}) / \mathrm{ST})
$$

where ST is the total number of taxa observed in a year and $\mathrm{S}$ is the average number of taxa observed in single samples. P, which varies between 0 and 1 , represents the fraction of species that are present in each sample throughout the year. If $\mathrm{P}$ value is close to 0 , the majority of taxa were found only once, while if it is close to 1 they populated most samples.

To help interpret the recent persistence patterns in Lake Orta, we calculated the persistence of zooplankton taxa in Lake Maggiore for years 2001 and 2007. Lake Maggiore is another subalpine lake that is close to Lake Orta and located in the same catchment basin. Unlike Lake Orta, it never acidified, and its zooplankton community was never decimated by acid or metal pollution. It thus can serve as a reasonable reference (Salmaso and Mosello, 2010). The zooplankton of Lake Maggiore was assessed in a identical manner to that of Lake Orta. 
To determine the role of the internal rotifer egg bank we compared the cumulative curve of rotifer resting eggs extracted from a Lake Orta sediment core previous analysed (Piscia et al., 2016) to the cumulative curve of annual new taxa. Between-sample differences in colonist taxa persistence, $\mathrm{P}$, were analyzed by the parametric Scheffé test, while Spearman's rank correlation coefficient, R, was used to test the statistical significance between cumulative data of rotifer resting egg and cumulative data of new taxa in the pelagic column. All tests were run in Statistica v. 12.

\section{RESULTS}

The total number of taxa encountered each year $\left(\mathrm{S}_{\text {total }}\right)$ in Lake Orta began to increase in the mid-1980s and has been steadily increasing ever since (Fig. 1). Except for copepods, for which $\mathrm{S}$ was quite constant $\left(\mathrm{S}_{\text {copepods }}=1-2\right.$ taxa $y^{-1}$ ) during the entire period, the mean annual richness, $\mathrm{S}$, of all other groups increased quite linearly. While the trends in $\mathrm{S}$ were positive for Cladocera, all Crustacea, and rotifers, the slopes did differ, at $0.15,0.20$ and 0.38 taxa $\mathrm{y}^{-1}$, respectively. $\mathrm{S}$ started to increase before liming, likely as consequence of early water-quality improvement, but it certainly increased continually after liming.

The number of taxa of both rotifers and crustacean zooplankton increased by about 4 fold over the record, but the largest absolute number of new taxa detected in Lake Orta were rotifers. The cumulative number of rotifer taxa detected (N) increased from 17 in 1971 to 81 in 2007, but, for Crustacea, the overall increase was more modest (i.e., from 7 in 1971 to 31 in 2007; Fig 2). Among crustaceans, the total increase of copepod species richness was very low (from 2 to 7); hence, it was colonizing Cladocera that dominated the crustacean time trend (Fig. 2). We can distinguish four phases in the species accumulation curve

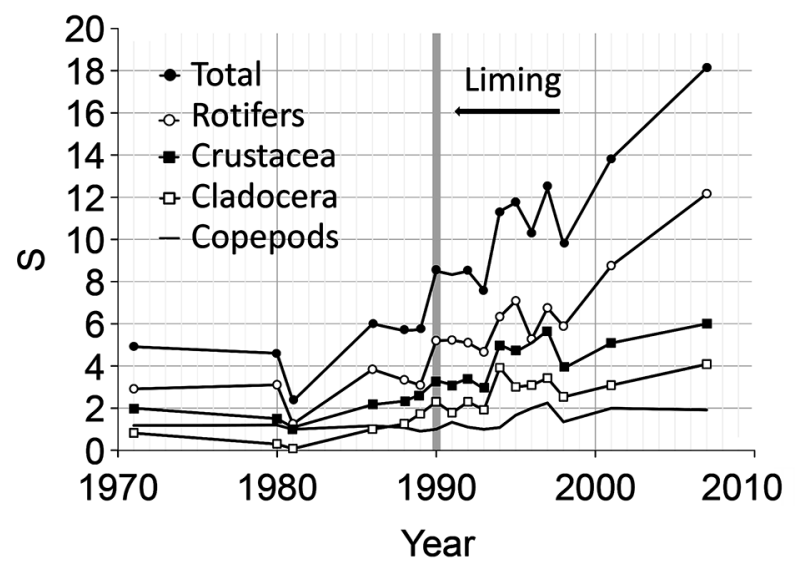

Fig. 1. Trend of average annual taxa richness (S) from 1971 to 2007 in Lake Orta. The gray bar indicates the liming period.
(N, Fig. 2). From 1971-1981 (Phase 1), N values for rotifer and crustaceans were quite stable, although only two years were sampled during this period. In Phase 1, chromium reached its maximum $\left(14 \mu \mathrm{g} \mathrm{L}^{-1}\right)$, copper was constant but elevated (ca. $50 \mu \mathrm{g} \mathrm{L}^{-1}$ ) and $\mathrm{pH}$ was very acid (between 4.20 and 4.57; Fig. 2). From 1981-1989 (Phase 2), $N_{\text {rotifer }}$ almost doubled from 22 to 39, while few taxa of crustaceans (Cyclops abyssorum, Eucyclops sp., Daphnia obtusa, Alona guttata, Bosmina sp.) colonized the lake $\left(\mathrm{N}_{\text {crustacea }}\right.$ increased from 8 to 13). During these years chromium concentration declined (from 7 to $2 \mu \mathrm{g} \mathrm{L}^{-1}$ ), copper concentration was around $40 \mu \mathrm{g} \mathrm{L}^{-1}$; in addition, pH was still very acid (ca. 4) reaching its minimum of 3.89 at winter mixing in 1985. During Phase 3 (19902001), immediately after liming, $\mathrm{N}_{\text {total }}$ initially increased very rapidly until 1995, reflecting the arrival of new rotifer and new cladocera taxa, while after 1995 the increase was due almost totally to Cladocera. Pelagic waters during

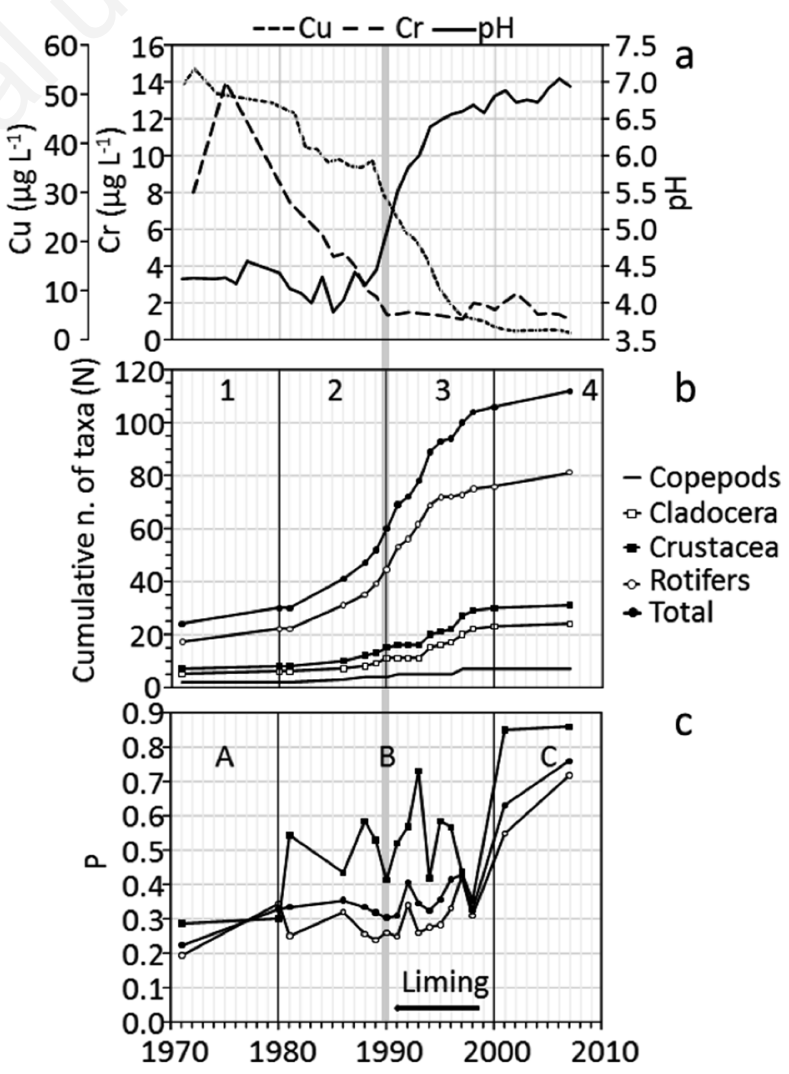

Fig. 2. a) pH and concentration of copper and chromium, calculated at winter overturn. b) Trend of cumulative number of new zooplankton taxa (N). c) Trend of annual persistence (P) of zooplankton organisms calculated for the main groups. All the data are referred to Lake Orta from 1971 to 2007 . Numbers and letters highlight different phases and the gray bar indicates the liming period (see text for further explanation). 
this period were characterized by a rapid increase of $\mathrm{pH}$ to values around neutrality, as a consequence of liming intervention (1989-1990), and by a very low concentration of metals, e.g. $\mathrm{Cu}$ declined from 30 to $2 \mu \mathrm{g} \mathrm{L}^{-1}$ and Cr stabilized at 1-2 $\mu \mathrm{g} \mathrm{L}^{-1}$. Finally, from 2001 to 2007 (Phase 4), we detected only a slight additional increase in $\mathrm{N}_{\text {rotiter }}$ (from 76 to 81 ) and $\mathrm{N}_{\text {crustacea }}$ (from 30 to 31), associated with the stabilization of good water quality in the lake, e.g., constant low levels of $\mathrm{Cu}$ and $\mathrm{Cr}$, and circumneutral $\mathrm{pH}$ (Fig 2). To detect the role of the rotifer egg bank we tested the correlation between the cumulative number of rotifer taxa $\left(\mathrm{N}_{\text {rotifer }}\right)$ and the cumulative curve of rotifer resting stages extracted from a sediment core (latter data from Piscia et al., 2016), which resulted not statistically significant (Spearman's $r=0.31, \mathrm{P}<0.05$ ).

Annual persistence (P) of taxa clearly increased over the period of observation, in 3 clearly discernable phases (Fig. 2). Annual persistence was lowest from 1971-1981, with both $\mathrm{P}_{\text {rotifer }}$ and $\mathrm{P}_{\text {crustacea }}$ values below 0.3 (0.19 and 0.29 , respectively). Thus, not only did few species appear in the lake, they did not persist for long in our collections, under the poor water quality conditions in the lake at that time (Fig. 2). From 1981-2001, annual persistence was very variable for crustacea, rising and falling between lows of 0.41 (1990) and highs of 0.73 (1993), while persistence of rotifer taxa was lower with a smaller range of values $(0.24-0.43)$. This period was characterized by the reduction of metal concentration in pelagic waters and by liming intervention, which restored $\mathrm{pH}$ to neutrality. Interestingly, annual $\mathrm{P}$ fell during the liming intervention, a short-lived negative consequence of liming on zooplankton that has also occurred in lakes elsewhere (Yan et al., 1996). Finally, from 2001-2007, $P_{\text {rotifer }}$ and $P_{\text {crustacea }}$ increased reaching their highest values in 2007 , i.e., 0.71 and 0.86 , respectively. During this recent period, few additional species appeared in the community (Fig. 2), but the resident species clearly had established populations that persisted for most of the year. In particular, both resident copepod species, 3 of 5 cladoceran species and 8 of 16 rotifer species were detected in every sample all year.

Annual persistence values in Lake Maggiore were comparable to those of crustaceans in Lake Orta during years 2001 and 2007. In fact, persistence of all crustaceans was as high (0.76 in 2001 and 0.74 in 2007) in Lake Maggiore as in Lake Orta (0.85 in 2001 and 0.86 in 2007). In contrast, persistence of rotifers in Lake Maggiore was much lower at 0.16 in 2001 and 0.12 in 2007 than in Lake Orta, where P for rotifers was 0.55 in 2001 and 0.71 in 2007. Statistical analysis (Scheffé test; Tab. 1) revealed that persistence of copepods has not changed during the different phases, while significant differences were observed for the other groups. In particular, persistence of cladocera, crustacea and rotifers has changed significantly between periods A and B (Tab. 1; Fig. 2), while the differ- ence was statistically significant only for total Crustacea and Rotifera between periods B and C.

\section{DISCUSSION}

The recolonization of an historically disturbed habitat is dependent upon both the rates of colonist arrival and by their ability to survive and persist in that habitat (Yan et al., 2016). In Lake Orta the quantity of colonists seems to be not a limiting factor as assessed by the increase of the average number of taxa per sample and the constant detection of new taxa (Figs. 1 and 2). In contrast, annual persistence of taxa was low and without significant changes until the end of 1990's, when persistence increased dramatically reaching the highest values. This result could be partly explained by chemical conditions. Concentrations of copper and chromium decreased steadily during our period of study, but concentrations were high enough to be toxic until the liming intervention (1989-1990; Fig. 2; Calderoni and Tartari, 2001). The tolerance to toxicants can vary greatly between zooplankton species and among clones within species (Stuhlbacher et al., 1992; Soares et al., 1992; Barata et al., 2002), but many studies confirm that the metal levels in Lake Orta were high enough to be toxic in the earlier part of our record. For example, Arnold et al. (2011) reported a $48-\mathrm{h} \mathrm{LC50}$ for $\mathrm{Cu}$ was $13.4 \mu \mathrm{gL}^{-1}$ for rotifer Brachionus plicatilis, while Bossuyt and Jansen (2005) reported a value of $22.6 \mu \mathrm{g} \mathrm{L}^{-1}$ for D. galeata inhabiting Lake Leuven, confirming the toxicity of Lake Orta waters. Moreover, previous ecotoxicological research (Ponti et al., 2010), conducted on Daphnia galeata from Lake Orta, showed that despite their high tolerance to copper (48-h EC50 $\left.=67.2 \mu \mathrm{g} \mathrm{L}^{-1}\right)$, these daphniids were already negatively affected by short exposures to a sub-lethal concentration of $6.9 \mu \mathrm{g} \mathrm{L}^{-1}$ of $\mathrm{Cu}$. Similar results were found by Coniglio and Baudo (1989) for Daphnia obtusa exposed to $\mathrm{Cr}$ from Lake Orta. While the D. obtusa that have populated the lake since 1986 (Bonacina, 2001) are quite tolerant to chromium (48h-LC50 $=61 \mu \mathrm{g} \mathrm{L}{ }^{-1}$ ), short-term exposures to $\mathrm{Cr}$ at comparable concentrations in the lake reduce animal demographic metrics (Coniglio and Baudo, 1989). In addition $\mathrm{Cu}$ and $\mathrm{Cr}$ were not the only metals present at elevated levels in the lake in those years (1971-

Tab.1. Comparison between the 3 phases (Scheffè Test) identified in persistence curves $(\mathrm{P})$ for different groups.

\begin{tabular}{lccc} 
& $\mathrm{A} / \mathrm{B}$ & $\mathrm{A} / \mathrm{C}$ & $\mathrm{B} / \mathrm{C}$ \\
$\mathrm{P}_{\text {cop }}$ & 0.699 & 0.225 & 0.334 \\
$\mathrm{P}_{\text {clad }}$ & 0.043 & $0.001^{* *}$ & 0.011 \\
\hline $\mathrm{P}_{\text {cru }}$ & 0.025 & $0.000^{* *}$ & $0.001^{* *}$ \\
$\mathrm{P}_{\text {rot }}$ & 0.900 & $0.000^{* *}$ & $0.000^{* *}$ \\
\hline $\mathrm{P}_{\text {tot }}$ & 0.177 & $0.000^{* *}$ & $0.000^{* *}$ \\
\hline
\end{tabular}


1990). Fe, Ni, Mn and Al were also a concern (Calderoni and Tartari, 2001) and the lake was also very acid. The negative effect of acidity on zooplankton is well documented in both field and laboratory studies (Keller et al., 1990; Havens et al., 1993). Many species cannot tolerate $\mathrm{pH}$ values lower than 5.5 and in that period the $\mathrm{pH}$ of Lake Orta was 4-4.5 at winter overturn. Finally, additive or perhaps synergistic negative effects of all of these factors are certainly possible.

The data in Fig. 2 represent conditions at winter overturn, a useful reference for long-term comparisons, but water quality varies with depth and season in Lake Orta. Zooplankton mainly occupy the top $50 \mathrm{~m}$ of the lake (Manca et al., 2000). In the euphotic zone (0-20m), pH increases to circum-neutral levels in the summer in response to phytoplankton photosynthesis (Rogora et al., 2016), allowing the establishment of chemical conditions favourable to the growth of zooplankton organisms. Persistence was also low after liming intervention, until the end of 1990s when $\mathrm{pH}$ was neutral and concentration of metals abated; therefore, during this period chemical conditions cannot explain our results. Certainly biological recovery occurs gradually and typically lags behind chemical recovery (Keller et al., 2002; Frost et al., 1998; Keller and Yan, 1991; Locke et al., 1994).

The total persistence curve mainly reflected the persistence of rotifers, which had by far the highest number of taxa in Lake Orta (Figs. 1 and 2). Cumulative new taxa and the average annual richness both suggest that biological recovery was not limited by the arrival of propagules, as observed in Sudbury lakes (Yan et al., 2016); in fact, we observed an increase of richness and a constant detection of new taxa since 1981. Cladocera and rotifers, and also some copepods, produce resting stages which can survive in sediments for decades (Hairston et al., 1995), where they constitute a genetic reserve of potential colonists (Hairston, 1996). Rotifer resting eggs extracted from a Lake Orta sediment cores confirm the presence of an egg bank (Piscia et al., 2012; Piscia et al., 2016). Both the composition (i.e., morphotypes) and the abundance of this internal reserve were related to the different phases of recovery in the lake. In addition, we found many open or empty cases of Brachionus calyciflorus resting eggs, evidence of attempts at recolonization of the lake. The hatching of these resting stages likely has contributed to the process of recolonization and could have affected the cumulative curve of new rotifer taxa, but statistical analysis did not support our hypothesis. In fact, we did not find a significant correlation between the cumulative curve of new rotifer taxa and the cumulative curve of new morphotypes of eggs in the sediment record. This result is easily explained. The attribution of morphotypes to rotifer species was not possible, and some of them were likely produced by benthic or littoral species which do not con- tribute to the pelagic population. Moreover, the abundance of organisms derived by the hatch of resting stages buried in Lake Orta sediments could be lower than our threshold of detection of pelagic taxa, or simply we could have missed them because they persisted in the water column for too short period of time. Moreover, while the cumulative curve for living rotifers tracked data from single years, data of the cumulative curve of resting eggs was from single layers of sediment core, which integrated at least 2 or 3 years.

Resting stages can be transported to a lake from within or beyond its catchment by migrating animals, rain and wind, all of which can contribute to the process of recolonization (Cáceres and Soluk, 2002; Incagnone et al., 2014). We cannot quantify the birds or insects vector, but we do not believe that increases in wind-induced dispersal account for the rising rate of species accumulation, because average wind speeds in the region decreased from the 1970s to 2005 (Ambrosetti et al., 2006). We also do not believe that human induced dispersal would have substantially increased over the last 40 years because the population increase until the mid-seventies has actually been fairly modest (Tonolli et al., 1975)

Total persistence was quite variable in the middle period (period B, Fig. 2), and it was reduced by liming. This also happened in Sudbury lakes (Yan et al., 1996), presumably because for species and clones that are adapted to acidity, rapid $\mathrm{pH}$ rise associated with liming, or the rapid precipitation and flocculation of metals associated with rising $\mathrm{pH}$ may actually be stressful.

After the sprinkling of carbonate, the waters of the lake were milky and this could negatively affect zooplankton organisms, or perhaps metal flocculation stripped them from the water column (Manca M., personal communication).

Persistence of total crustaceans was highest after 1981, while rotifer persistence was lowest at this time. This result was likely attributable in part to the lower annual average richness for crustacea compared with rotifers $\left(\mathrm{S}_{\text {crustacea }}=1.5\right.$ 6 taxa, $\mathrm{S}_{\text {rotifer }}=3.1-12.2$ taxa), and by a less marked seasonality of crustacean taxa, most of which were present the entire year. The high persistence of crustaceans may also be related to the absence of pelagic zooplanktivorous fish in Lake Orta (i.e., whitefish and shad; Volta et al., 2016). If this is the explanation for the high persistence, then the planned introduction of pelagic fish from 2016 to 2020 could modify the seasonality and thus the annual persistence of crustacean zooplankton in the lake.

High persistence certainly contributes to high average species richness, but it is not always a sign of ecological recovery. Annual persistence of rotifers $\left(\mathrm{P}_{\text {rotifer }}\right)$ was very low $(2001=0.16$ and 2007 $=0.12)$ in Lake Maggiore compared to Lake Orta. The simplest explanation for this difference is the presence in Lake Maggiore of the two pelagic macroinvertebrate zooplanktivores Leptodora and 
Bythotrephes, which have been shown to regulate the abundance of rotifers and small crustaceans (de Bernardi et al., 1987; Manca and Comoli, 1995), reducing their population size below our detection limits on occasion and thus lowering their annual persistence. These two predators are still absent from Lake Orta, allowing unharvested prey populations to persist much of the year. Before industrial pollution, the zooplanktonic populations of Lake Orta and Lake Maggiore were similar (Salmaso and Mosello, 2010). Pioneering limnological studies reported that zooplankton were very abundant and diverse in Lake Orta, the community including Daphnia spp., cyclopoids, diaptomids, Leptodora sp., Sida sp., Bosmina spp., Diaphanosoma brachyurum, Asplanchna priodonta, Kellicotia longispina, Keratella cochlearis and Polyarthra platyptera (Monti, 1930). Zooplankton disappeared in the water column after the beginning of industrial pollution and Leptodora, diaptomids and Sida remain absent to this day. Sida crystallina was also present in Lake Maggiore until 1967 (Manca and Comoli, 1995) when the lake was undergoing rapid eutrophication. Diaptomids are very important in Lake Maggiore, but they disappeared from Lake Orta after the pollution, while they have recolonized historically acidified Sudbury lakes (Locke et al., 1994; Arnott et al., 2001), including limed lakes (Yan et al., 2004). Their lack of recovery in Lake Orta might be linked to their lack of production of resting stages, and to the fact that Lake Orta waters flow into Lake Maggiore, while recovering Sudbury lakes are surrounded by many lakes which can provide colonists.

\section{CONCLUSIONS}

In this study we analyzed recent zooplankton data from Lake Orta in order to understand broad-scale drivers of their recovery after 80 years of acid and metal contamination and a restorative liming intervention. Following Yan et al. (2016), we used the annual persistence of zooplankton species as one parameter to estimate the mechanism underpinning zooplankton recovery. Contrary to Middle and Clearwater lakes in Sudbury (Yan et al., 2016), the only other lakes where this metric has been used, annual persistence has changed over time in Lake Orta, suggesting that different processes regulate recovery of richness in these case studies. The lack of pelagic fish predators (Volta et al., 2016) in Lake Orta could provide the explanation. Planktivorous fish populations increased after liming in Sudbury lakes (Yan et al., 2016). In contrast in Lake Orta, not only have pelagic species of zooplanktivorous fish not yet returned, but the large native predatory cladocerans, Bythotrephes and Leptodora, which are common in the nearby Lake Maggiore, have not yet returned to Lake Orta. In particular, we hypothesize that the unusually high annual persistence of rotifers in Lake Orta in comparison to Lake Maggiore is related to the absence of the top-down control from cladoceran predators. Should they reinvade Lake Orta, we suspect that a more typical seasonality of rotifers may reoccur.

In summary, our examination of three zooplankton richness metrics results suggests that the recovery of the zooplankton community of Lake Orta was not limited by the arrival of new colonists but that the bottleneck was the ability of organisms to survive and thrive in the lake, confirming that annual persistence and taxa accumulation parameters can help provide understanding of mechanisms underlying the recovery of zooplankton. When compared with Lake Maggiore, our results also suggest that not all increases in annual persistence suggest recovery, rather if much higher than reference systems they may suggest a transient state of recovery brought on by unusually low predation pressure in the absence of both planktivorous fish and predatory Cladocera.

\section{REFERENCES}

Ambrosetti W, Barbanti L, Rolla A, 2006. The climate of Lago Maggiore area during the last fifty years. J. Limnol. 65 (1s):1-62.

Arnott SE, Yan N, Keller W, Nicholls K, 2001. The influence of drought-induced acidification on the recovery of plankton in Swan Lake (Canada). Ecol. Appl. 11:747-763.

Barata C, Baird DJ, Mitchell SE, Soares AM, 2002. Among-and within-population variability in tolerance to cadmium stress in natural populations of Daphnia magna: implications for ecological risk assessment. Environ. Toxicol. Chem. 21: 1058-1064.

Bossuyt BTT, Janssen CR, 2005. Copper toxicity to different field-collected cladoceran species: intra- and interspecies sensitivity. Environ. Pollut. 136:145-154.

Cáceres CE, Soluk DA, 2002. Blowing in the wind: a field test of overland dispersal and colonization by aquatic invertebrates. Oecologia 131:402-408.

Calderoni A, Mosello R, Quirci A, de Bernardi R, 1990. Recovery of Lake Orta by liming. Proc. VII Int. Lime Congr., Rome, Italy, pp. 157-171.

Calderoni A, Tartari GA, 2001. Evolution of the water chemistry of Lake Orta after liming. J. Limnol. 60:69-78.

Coniglio L, Baudo R, 1989. Life-tables of Daphnia obtusa (Kurz) surviving exposure to toxic concentrations of chromium. Hydrobiologia 188:407-410.

Bonacina C, 2001. Lake Orta: the undermining of an ecosystem. J. Limnol. 60: 49-57.

de Bernardi R, 1984. Methods for the estimation of zooplankton abundance. A manual on methods for the assessment of secondary productivity in fresh waters. 2nd ed. IBP Handbook 17:59-86.

de Bernardi R, Giussani G, Manca M, 1987. Cladocera: predators and prey. Hydrobiologia 145:225-243.

Dillon PJ, Reid RA, De Grosbois E, 1987. The rate of acidification of aquatic ecosystems in Ontario, Canada. Nature 329:45-48.

Frost TM, Montz PK, Kratz TK, 1998. Zooplankton community responses during recovery from acidification in Little Rock Lake, Wisconsin. Rest. Ecol. 6:336-342. 
Gray DK, Arnott SE, Shead JA, Derry AM, 2012. The recovery of acid-damaged zooplankton communities in Canadian lakes: the relative importance of abiotic, biotic and spatial variables. Freshwater Biol. 57:741-758.

Hairston NG Jr, 1996. Zooplankton egg banks as biotic reservoirs in changing environments. Limnol. Oceanogr. 41:1087-1092.

Hairston NG Jr, Van Brunt RA, Kearns CM, 1995. Age and survivorship of diapausing eggs in a sediment egg bank. Ecology 76:1706-1711.

Havens KE, Yan ND, Keller W, 1993. Lake acidification effects on crustacean zooplankton populations. Env. Sci. Technol. 27:1621-1624.

Hebert PD, Cristescu ME, 2002. Genetic perspectives on invasions: the case of the Cladocera. Can. J. Fish. Aquat. Sci. 59:1229-1234.

Henriksen A, Lien L, Traaen TS, Sevaldrud IS, Brakke DF, 1988. Lake acidification in Norway-present and predicted chemical status. Ambio 17:259-266.

Incagnone G, Marrone F, Barone R, Robba L, Naselli-Flores L, 2015. How do freshwater organisms cross the "dry ocean"? A review on passive dispersal and colonization processes with a special focus on temporary ponds. Hydrobiologia 750:103-123.

Keller W, Yan ND, 1991. Recovery of crustacean zooplankton species richness in Sudbury area lakes following water quality improvements. Can. J. Fish. Aquat. Sci. 48:1635-1644.

Keller W, Yan ND, Gunn JM, Heneberry J, 2007. Recovery of acidified lakes: lessons from Sudbury, Ontario, Canada. Water Air Soil Pollut. Focus 7:317-322.

Keller W, Yan ND, Holtze KE, Pitblado JR, 1990. Inferred effects of lake acidification on Daphnia galeata mendotae. Environ. Sci. Technol. 24:1259-1261.

Keller W, Yan ND, Somers KM, Heneberry JH, 2002. Crustacean zooplankton communities in lakes recovering from acidification. Can. J. Fish. Aquat. Sci. 59:726-735.

Locke A, Sprules WG, Keller W, Pitblado JR, 1994. Zooplankton communities and water chemistry of Sudbury area lakes: changes related to $\mathrm{pH}$ recovery. Can. J. Fish. Aquat. Sci. 51: 151-160.

Manca M, Calderoni A, Mosello R, 1992. Limnological research in Lago Maggiore: studies on hydrochemistry and plankton. Mem. Ist. Ital. Idrobiol. 50:171-200.

Manca M, Cavicchioni N, Morabito G, 2000. First observations on the effect of a complete, exceptional overturn of Lake Maggiore on plankton and primary productivity. Int. Rev. Hydrobiol. 85:209-222.

Manca M, Comoli P, 1995. Temporal variations of fossils Cladocera in the sediments of Lake Orta (N. Italy) over the last 400 years. J. Paleolimnol. 14:113-122.

Monti R, 1930. La graduale estinzione della vita nel limnobio del Lago d'Orta. Rend. Ist. Lomb. Sci. Lett. 63:3-22.

Monteith DT, Hildrew AG, Flower RJ, Raven PJ, Beaumont WRB, Collen P, Kreiser AM, Shilland EM, Winterbottom JH, 2005. Biological responses to the chemical recovery of acidified fresh waters in the UK. Environ. Pollut. 137:83-101.

Piscia R, Guilizzoni P, Fontaneto D, Vignati DA, Appleby PG, Manca M, 2012. Dynamics of rotifer and cladoceran resting stages during copper pollution and recovery in a subalpine lake. Int. J. Limnol. 48: 151-160.

Piscia R, Tabozzi S, Bettinetti R, Nevalainen L, Manca M, 2016. Unexpected increases in rotifer resting egg abundances during the period of contamination of Lake Orta. J. Limnol. 75(Suppl.2):76-85.

Ponti B, Piscia R, Bettinetti R, Manca M, 2010. Long-term adaptation of Daphnia to toxic environment in Lake Orta: the effects of short-term exposure to copper and acidification. J. Limnol. 69:217-224.

Ramoni C, 1997. [Dinamica stagionale delle comunità zooplanctonica e fitoplanctonica del Lago Maggiore nel corso del 1996].[Master Thesis in Italian]. University of Milan, Italy.

Renberg I, Brodin YW, Cronberg G, El-Daoushy F, Oldfield F, Rippey B, Sandoy S, Wallin JE, Wik M, 1990. Recent acidification and biological changes in Lilla Oresjon, southwest Sweden, and the relation to atmospheric pollution and landuse history. Philos. T. R. Soc.. B 327:391-396.

Rogora M, Kamburska L, Mosello R, Tartari GA, 2016. Lake Orta chemical status 25 years after liming: problems solved and emerging critical issues. J. Limnol. 75(Suppl.2):93-106.

Salmaso N, Mosello R, 2010. Limnological research in the deep southern subalpine lakes: synthesis, directions and perspectives. Adv. Oceanogr. Limnol. 1:29-66.

Signorini C, 2005. [Lo zooplancton del lago d'Orta nel 2001: condizioni attuali e confronto con la situazione precedente].[Master Thesis in Italian]. University of Milan, Italy.

Soares AM, Baird DJ, Calow P, 1992. Interclonal variation in the performance of Daphnia magna Straus in chronic bioassays. Environ. Toxicol. Chem. 11:1477-1483.

Stuhlbacher A, Bradley MC, Naylor C, Calow P, 1992. Induction of cadmium tolerance in two clones of Daphnia magna Straus. Comp. Biochem. Phys. C 101:571-577.

Sturman A, Wanner H, 2001. A comparative review of the weather and climate of the Southern Alps of New Zealand and the European Alps. Mt. Res. Dev. 21:359-369.

Tonolli L, Gerletti M, Chiaudani G, 1975. Trophic conditions of Italian lakes as a consequence of human pressures, p. 215225. In: A. Hasler (ed.), Coupling of land and water systems. Springer.

Volta P, Yan ND, Gunn JM, 2016. Past, present and future of the fish community of Lake Orta (Italy), one of the world's largest acidified lake. J. Limnol. 75(Suppl.2):131-141.

Williamson M, 1996. Biological invasions. 15. Springer, London: $244 \mathrm{pp}$.

Yan ND, Bailey J, McGeer JC, Manca M, Keller WB, Celis-Salgado MP, Gunn J, 2016. Arrive, survive and thrive: the essential stages in the re-colonization and recovery of zooplankton in urban lakes in Sudbury, Canada. J. Limnol. 75(Suppl.2):4-14.

Yan ND, Girard R, Heneberry JH, Keller WB, Gunn JM, Dillon PJ, 2004. Recovery of Copepod, but not Cladoceran, zooplankton from severe and chronic effects of multiple stressors. Ecol. Lett. 7:452-460.

Yan ND, Keller W, Somers KM, Pawson TW, Girard RE, 1996. The recovery of crustacean zooplankton communities from acidification: comparing manipulated and reference lakes. Can. J. Fish. Aquat. Sci. 53:1301-1327. 